\title{
Erratum to: Genotypic Characterization of Environmental Isolates of Cryptococcus gattii from Puerto Rico
}

\author{
Yaliz Loperena-Alvarez • Ping Ren · Xiaojiang Li • \\ Dianna J. Schoonmaker-Bopp • Alejandro Ruiz • \\ Vishnu Chaturvedi · Carlos Rios-Velazquez
}

Published online: 13 July 2010

(C) Springer Science+Business Media B.V. 2010

\section{Erratum to: Mycopathologia DOI 10.1007/s11046-010-9296-3}

A number of errors have gone uncorrected in the manuscript. Importantly, mating type assignments were incorrect for the samples initially examined in this study. Mating type determination was repeated by the laboratory at Albany after receiving a note from Drs. Carlos Rios-Velazquez and Alejandro Ruiz about ongoing study of Dr. Edmond J. Byrnes III in the laboratory of Dr. Joe Heitman at Duke University. According to Dr. Byrnes unpublished findings most of the C. gattii isolates from Puerto Rico are MATa. We have also found similar results after repeating this part of the experiments. We would like to make following corrections:

Yaliz Loperena-Alvarez and Ping Ren contributed equally to this work.

The online version of the original article can be found under doi:10.1007/s11046-010-9296-3.

Y. Loperena-Alvarez · A. Ruiz · C. Rios-Velazquez ( $ه)$ University of Puerto Rico at Mayagüez, Mayagüez, PR, USA

e-mail: crioslab@gmail.com

P. Ren · X. Li - D. J. Schoonmaker-Bopp - V. Chaturvedi New York State Department of Health, Wadsworth Center, Albany, NY, USA
Author list

Yaliz Loperena-Alvarez, Ping Ren, Xiaojiang Li, Dianna J. Schoonmaker-Bopp, Alejandro Ruiz, Vishnu Chaturvedi, Carlos Rios-Velazquez

Yaliz Loperena-Alvarez and Ping Ren contributed equally to this work.

\section{Abstract, p. 1}

Line 9: "Cryptococcus" should be italicized as "Cryptococcus".

Line 14: "MAT strains" should be "majority of them were MATa strains".

Figure 1, Legend, p. 3

Delete "(arrow indicates sample lesion)"

Delete "the arrows indicate the detritus collected and the hole sampled"

\section{Mating Type Determination by PCR Pheromone Genes, p. 4}

Left column 1st paragraph last sentence (line 913): "PCR ...mating types." should be "The new primer pairs of V1823 (5'-CGCGATGTTGGCTGTA ATGG-3'), V1824 (5'-ATAAAAAGTTCGAGGTTT CCCAC- $\left.3^{\prime}\right)$ and V1825 (5'-TAAGGAGAAAGAGC GACGTC- $\left.3^{\prime}\right)$, V1826 (5'GGCATGTTCAATTGGG TTGC- $3^{\prime}$ ) were designed for PCR-Sequencing of $M F \alpha 1$ and $M F a l$ gene fragments from Cryptococcus gattii, because previous primer set V191 -192 works 
best when it is used only for mating type screening on special gel; we have now confirmed that this primer set is not useful for nucleotide sequencing owing to the small size of the amplicons. The MATa sequences were submitted to Gene Bank under the accession numbers HM535310-HM53526.

\section{Results and Discussion, p. 4}

Line 2: Number " 22 " should be "23 with one sample found non-viable subsequently"

\section{Table 1, p. 4}

Total number of samples collected should be "710" instead of "705". Total positive samples should be " 23 " instead of " 22 ".

\section{Results and Discussion, p. 5}

Left column 2nd paragraph 1st sentence (line 19-21): "Flow cytometry ... being C. gattii." should be read as "Flow cytometry analysis demonstrated that all 22 isolates were haploid. Seventeen isolates were $C$. gattii; subsequent typing showed 16 of the 17 isolates to be MATa." Right column line 5: "similar to" should be "different from".

Right column line 9-12: "Perhaps, the relative number ... is present in Puerto Rico." should be "Surprisingly, MATa strains were dominant relative to MAT $\alpha$ in the environment in Puerto Rico area".

\section{References, pp. 6-7}

There are no numbers assigned to references in the bibliography to match with number of cited reference in the text. Corrected list of the references is as follows:

1. Abegg MA, Cella FL, Faganello J, Valente P, Schrank A, Vainstein MH. Cryptococcus neoformans and Cryptococcus gattii isolated from the excreta of psittaciformes in a southern Brazilian zoological garden. Mycopathologia. 2006;161:83-91.

2. Barreto de Oliveira MT, Boekhout T, Theelen B, Hagen F, Baroni FA, Lazera MS, et al. Cryptococcus neoformans shows a remarkable genotypic diversity in Brazil. J Clin Microbiol. 2004;42:1356-9.

3. Boekhout T, Theelen B, Diaz M, Fell JW, Hop WCJ, Abeln ECA, et al. Hybrid genotypes in the pathogenic yeast Cryptococcus neoformans. Microbiology. 2001;147:891-907.

4. Bovers M, Hagen F, Kuramae FE, Hoogveld HL, Dromer F, St-Germain G, et al. AIDS patient death caused by novel Cryptococcus neoformans $\times C$. gattii hybrid. Emerg Infect Dis. 2008; $14: 1105-8$.

5. Bovers M, Hagen F, Kuramae EE, Díaz MR, Spanjaard L, Dromer F, et al. Unique hybrids between the fungal pathogens Cryptococcus neoformans and Cryptococcus gattii. FEMS Yeast Res. 2006;6:599-607.

6. Callejas A, Ordoñez N, Rodríguez MC, Castañeda E. First isolation of Cryptococcus neoformans var. gattii, serotype $\mathrm{C}$, from the environment in Colombia. Med Mycol. 1998;36:341-4.

7. Casadevall A, Perfect JR. Cryptococcus neoformans. Washington, DC: ASM Press; 1998.

8. Castañeda E. Isolation, identification, serotype determination and sexual stage manual: ecology, physiology and molecular biology of Cryptococcus neoformans. Colombia: National Institute of Health in Colombia; 2000.

9. Chaturvedi S, Rodeghier B, Fan J, McClelland CM, Wickes BL, Chaturvedi V. Direct PCR of Cryptococcus neoformans MAT $\alpha$ and MATa pheromones to determine mating type, ploidy, and variety: a tool for epidemiological and molecular pathogenesis studies. J Clin Microbiol. 2000;38:2007-9.

10. Chaturvedi S, Dyavaiah M, Larsen RA. Chaturvedi, V. Cryptococcus gattii in AIDS patients, southern California. Emerg Infect Dis. 2005; 11:1686-92.

11. Duncan C. The emergence of Cryptococcus gattii in British Columbia: veterinary aspects. Thesis MS. University of Saskatchewan, Saskatoon. 2005.

12. Ellis D, Pfeiffer TJ. Natural habitat of Cryptococcus neoformans var. gattii. J Clin Microbiol. 1990;28:1642-4.

13. Farnsworth B. A guide to trails of Guánica state forest biosphere reserve. Puerto Rico: Department of Natural Resources of Puerto Rico; 1991. 
14. Gente S, Sohier D, Coton E, Duhamel C. Identification of Geotrichum candidum at the species and strain level: proposal for a standardized protocol. J Ind Microbiol Biotechnol. 2006;33:1019-31.

15. Halliday CL, Bui T, Krockenberger M, Malik R, Ellis DH, Carter DA. Presence of $\alpha$ and a mating types in environmental and clinical collections of Cryptococcus neoformans var. gattii strains from Australia. J Clin Microbiol. 1999;37:2920-6.

16. Kidd SE, Hagen F, Tscharke RL, Huynh M, Bartlett H, Fyfe M, et al. A rare genotype of Cryptococcus gattii caused the cryptococcosis outbreak on Vancouver Island (British Columbia, Canada). PNAS. 2004;101:1725863.

17. Kidd SE, Chow Y, Mak S, Bach PJ, Chen H, Hingston AO, et al. Characterization of environmental sources of the human and animal pathogen Cryptococcus gattii in British Columbia, Canada, and the pacific Northwest of the United states. Appl Environ Microbiol. 2007; 73:1433-43.

18. Kwon-Chung KJ, Boekhout T, Fell JW, Diaz M. Proposal to conserve the name Cryptococcus gattii against $C$. hondurianus and $C$. bacillisporus (Basidiomycota, Hymenomycetes, Tremellomycetidae). Taxon. 2002;51:804-6.

19. Kwon-Chung KJ, Polacheck I, Bennett JE. Improved diagnostic medium for separation of Cryptococcus neoformans var. neoformans (serotypes A and D) and Cryptococcus neoformans var. gattii (serotypes B and C). J Clin Microbiol. 1983;15:535-7.

20. Lazera MS, Salmito Cavalcanti MA, Londero AT, Trilles L, Nishikawa MM, Wanke B. Possible primary ecological niche of Cryptococcus neoformans. Med Mycol. 2000;38: 379-83.

21. Lizarazo J, Linares M, de Bedout C, Restrepo A, Agudelo CI, Castañeda E. Grupo Colombiano para el Estudio de la Criptococosis. Results of nine years of the clinical and epidemiological survey on cryptococcosis in Colombia, 19972005. Biomedica. 2007;27:94-109.

22. MacDougall L, Fyfe M. Emergence of Cryptococcus gattii in a novel environment provides clues to its incubation period. J Clin Microbiol. 2006;44:1851-2.

23. Meyer W, Marszewska K, Amirmostofian M, Igreja RP, Hardtke C, Methling K, et al. Molecular typing of global isolates of Cryptococcus neoformans var. neoformans by polymerase chain reaction fingerprinting and randomly amplified polymorphic DNA-a pilot study to standardize techniques on which to base a detailed epidemiological survey. Electrophoresis. 1999;20:1790-9.

24. Meyer W, Castaneda A, Jackson S, Hyynh M, Castaneda E, The IberoAmerican Cryptococcal Study Group. Molecular typing of IberoAmerican Cryptococcus neoformans isolates. Emerg Infect Dis. 2003;9:189-95.

25. Pérez J. Aspectos ecológicos y epidemiológicos de Cryptococcus neoformans en Puerto Rico. MS Thesis. University of Puerto Rico-Mayagüez. 1996.

26. Randhawa HS, Kowshik T, Khan ZU. Efficacy of swabbing versus a conventional technique for isolation of Cryptococcus neoformans from decayed wood in tree trunk hollows. Med Mycol. 2005;43:67-71.

27. Refojo N, Perrotta D, Brudny M, Abrantes R, Hevia AI, Davel G. Isolation of Cryptococcus neoformans and Cryptococcus gattii from trunk hollows of living trees in Buenos Aires City, Argentina. Med Mycol. 2009;47:177-84.

28. Ruiz A, Fromtling RA, Bulmer GS. Distribution of Cryptococcus neoformans in a nature site. Infect Immun. 1981;31:560-3.

29. Ruiz A, Vélez D, Fromtling RA. Isolation of saprophytic Cryptococcus neoformans form Puerto Rico: distribution and variety. Mycopathologia. 1989;106:167-70.

30. Springer DJ, Chaturvedi V. Projecting global occurrence of Cryptococcus gattii. Emerg Infect Dis. 2010;16:14-20.

31. Staib FB, Grave B, Altmann L, Mishra SK, Abel T, Blisse A. Epidemiology of Cryptococcus neoformans. Mycopathologia. 1973;65:73-6.

32. Trilles L, Lazéra Mdos S, Wanke B, Oliveira RV, Barbosa GG, Nihikawa MM, et al. Regional pattern of the molecular types of Cryptococcus neoformans and Cryptococcus gattii in Brazil. Mem Inst Oswaldo Cruz. 2008;103:455-62. 